\title{
Use of quality tools to evaluate forest seedlings production in the nursery stage
}

\author{
Rafael Eloy de Souza ${ }^{1}$ Alfredo José dos Santos Junior $\mathbb{1 0}^{2 *}$ Alan Henrique Marques de Abreu ${ }^{3}$ Natália \\ Dias de Souza ${ }^{1}$ Ananias Francisco Dias Júnior ${ }^{2}$ \\ ${ }^{1}$ Universidade Federal Rural do Rio de Janeiro, Km 07, Zona Rural, BR-465, 23890-000, Seropédica - RJ, Brasil \\ ${ }^{2}$ Universidade Federal do Espírito Santo. Avenida Fernando Ferrari, 514 - Goiabeiras, 29075-910, Vitória - ES,Brasil \\ ${ }^{3}$ Companhia Estadual de Águas e Esgotos do Rio de Janeiro, Avenida Presidente Vargas, 2655 - Cidade Nova 20210-030, Rio de Janeiro - \\ RJ, Brasil
}

\section{Original Article \\ *Corresponding author: alf.junior12@gmail.com \\ Keywords: \\ Evaluation of non- conformity \\ Quality management \\ Native forest seedlings \\ Pareto chart}

Statistical process control

Palavras-chave:

Avaliação de nãoconformidade

Manejo da qualidade

Mudas de florestas nativas

Gráfico de Pareto

Controle estatístico de processos

Received in

2020/07/02

Accepted on

2021/07/01

Published in 2021/08/31

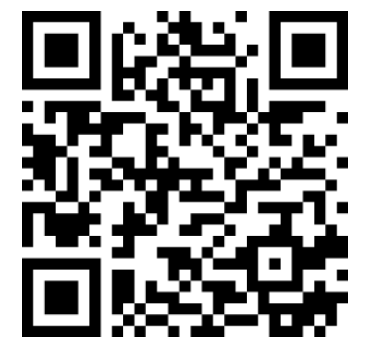

DOI: http://dx.doi.org/ 10.34062/afs.v8i1.10765
ABSTRACT: The control of production processes can assist in the standardization of variability, reducing waste, and improving the quality of a service or product. Thus, this study aimed to analyze the non-conformities in a production system of forest seedlings from Atlantic Forest aiming at the standardization of the production system and adjustments for field cultivation. The definition of the attributes was made through a technical visit to the forestry nursery to know the location and the production process of the seedlings. For the process evaluation, statistical process control tool was used. The non-conformities analyzed were coiled root growth, disintegrated substrates of plants, presence of roots fixed to the ground, presence of phytopathogen attack symptoms and/or herbivory and symptoms of nutritional deficiency. In general, variability was detected in the production process, compromising the success in planting the seedlings in the field, as well as their quality.

\section{Uso de ferramentas de qualidade para avaliar a produção de mudas florestais na fase de viveiro}

RESUMO: O controle dos processos de produção pode auxiliar na padronização da variabilidade, reduzindo o desperdício e melhorando a qualidade de um serviço ou produto. Assim, este estudo teve como objetivo analisar as não-conformidades em um sistema de produção de mudas florestais da Mata Atlântica, visando à padronização do sistema de produção e ajustes para o cultivo em campo. A definição dos atributos foi feita através de uma visita técnica ao viveiro florestal para conhecer a localização e o processo de produção das mudas. Para a avaliação do processo, foi utilizada a ferramenta de controle estatístico do processo. As nãoconformidades analisadas foram: crescimento das raízes em espiral, substratos desintegrados das plantas, presença de raízes fixadas ao solo, presença de sintomas de ataque de fitopatógenos e/ou herbivoria e sintomas de deficiência nutricional. De forma geral, foi detectada variabilidade no processo de produção, comprometendo o sucesso no plantio das mudas no campo, bem como sua qualidade. 


\section{Introduction}

The demand for the Rural Environmental Registry and the Environmental Regularization Program, supported by the Federal Law 12.651, in the current Brazilian scenario has been one of the contributing factors to the increased demand for seedlings and seeds of species from the Atlantic Forest to promote the restoration of Permanent Preservation Areas as well as Legal Reserve Areas (Silva et al. 2015; Alarcon et al. 2017; Alves-Pinto et al. 2017). However, the use of seedlings that are of inferior quality for planting, has resulted in high mortality rates and decreased post-planting growth rate, directly impacting the productivity and expenses of constituting the forests that should be formed (Gregorio et al. 2017; Grossnickle and MacDonald 2018a; Grossnickle and MacDonald $2018 b$ ). The positive result of a program for the planting, revitalization, and restoration of native forests, is related to the procedures and systems used by "nurserymen" in the production of high-quality seedlings, aiming at an efficient restoration process (Haase and Davis 2017).

To carry out the seedling production process efficiently and in a standardized manner, it is necessary to identify possible trends of nonconformities in the seedlings, and in this context, conduct the regularization of the process through corrective measures, resulting in savings of resources and time (Grossnickle and MacDonald 2018b). The quality of the seedlings must be guaranteed even in the nursery, before dispatch, to ensure that they are suitable for planting in the field, improving the productivity and homogeneity of the forests (Haase and Davis 2017; Moreno et al. in press).

An alternative to control the production of seedlings is to employ quality tools to facilitate the increase in production efficiency while the seedlings are in the nursery. Statistical process control (SPC) allows analyzing the constancy of the production system, identifying variability, raising nonconformities, and, from there, reassessing the process aiming at reducing deviations and at better conduct in the production of the final product (Montgomery 2012). With the use of SPC, the processes can be controlled with the survey of attributes of interest over time, in which the results are recorded in control charts (Lima 2006; Trindade et al. 2007; Bottani et al. 2021; Kim and Lim 2021).

The excess of non-conformities during the seedling production phase can cause negative quality aspects when the seedling is used (e.g., forest restoration). The detection and subsequent correction of non-conformities would result in a standardized system producing forest seedlings of high quality, more rustic and resistant and, consequently, with a greater capacity to withstand the obstacles of the field, such as drought and nutritional stress, and pest attack, enabling the best formation of forest stand, reducing implementation failure, and avoiding expenses with possible maintenance (Du et al. 2020; Reis et al. 2021). Given the above, this study aimed to evaluate nonconformities in a production system of forest seedlings in the Atlantic Forest aiming at standardizations of the production system and adaptations for field cultivation.

\section{Material and Methods}

This work was carried out in the forest nursery of the State Water and Sewage Company of Rio de Janeiro (CEDAE), located in the Agricultural Penal Colony Marco Aurélio Vergas Tavares de Mattos, in the Magé city, Rio de Janeiro, Brazil. The activities of the production of forest seedlings as well as the activities of forest restoration that occur in this nursery are carried out by forty inmates in a semiopen regime employed by CEDAE. The nursery's primary guideline is to meet the Company's environmental interventions, such as forest restoration of areas close to springs, recovery of degraded areas, environmental education, and, occasionally, provides forest seedlings for environmental projects from partner institutions that share the same purposes. The seedlings produced in this nursery are not commercialized.

The nursery has a production capacity of approximately 1.2 million seedlings per year, using $14 \times 20 \mathrm{~cm}$ plastic bags as containers, in a total area of $31.000 \mathrm{~m}^{2}$. The substrate used in the production of the seedlings is composed of a mixture of $50 \%$ clay and $50 \%$ sewage sludge from the Ilha do Governador ETE and does not use basal or top-dressing chemical fertilization during the production cycle. The nursery produces a high diversity of forest seedlings, sometimes working with more than 200 species over the course of a year, focusing mainly on fruit species from the Atlantic Forest and endangered species. At the time of this study the nursery was working with seedlings of 53 different forest species, germinated from seeds obtained from the nearing forests.

To define the non-conformities evaluated in this study, technical visits were made to the nursery in order to know the location and production processes, in addition to interviews with questionnaires to those responsible for the manufacture of forest seedlings, from a brainstorming session. Non-conformities and their possible causes and consequences are described in Table 1 . 
Souza et al.

Table 1. Survey of non-conformities.

\begin{tabular}{ccc}
\hline Non-conformities & Possible causes & Possible consequences \\
Disintegrating substrates & $\begin{array}{c}\text { Inadequate filling of containers; } \\
\text { inadequate substrate }\end{array}$ & Damage to roots at the time of planting \\
Coiled root growth & $\begin{array}{c}\text { Error in transplanting; seedlings } \\
\text { exceeding the dispatch time }\end{array}$ & $\begin{array}{c}\text { Seedling mortality or growth } \\
\text { retardation after planting }\end{array}$ \\
Roots fixed to the ground & $\begin{array}{c}\text { Seedlings exceeding the } \\
\text { dispatch time } \\
\text { Lutritional deficiency }\end{array}$ & $\begin{array}{c}\text { Stress and damage to the root system } \\
\text { fertilization }\end{array}$ \\
Attack of pathogens and \\
herbivores
\end{tabular}

Data were collected during 2017 through individual assessment and destructive analysis of 400 seedlings, with different ages. The seedlings were separated into 40 samples containing 10 seedlings each. To compose these samples, ten seedlings of the species that were been produced at the moment of this study were randomly selected in the seedling dispatch beds.

The seedlings evaluated were those that were stored in the dispatch area of the nursery, that is, those considered fit to be sent for planting in the field, as stipulated by the nursery's technical team. After removing and separating the seedlings, nonconformities were surveyed. The first nonconformity raised was the presence of seedlings with roots attached to the soil, when the existence of roots external to the container fixed to the soil of the nursery was observed. Then, the existence of visual symptoms of an attack of phytopathogens and/or herbivory and symptoms of nutritional deficiency, was observed. The observation of the other nonconformities required the destructive analysis of the seedlings.

To analyze whether the clod in the substrate was well-formed, the plastic bags were opened with the help of a cutting object, reproducing what happens in a field situation. Seedlings whose substrate was disintegrated were considered nonconformities. Then, the substrate was washed to verify the last non-conformity: the existence of entanglements in the roots.

To assess whether the samples showed a normalized distribution at $95 \%$ probability, the data collected underwent the Shapiro-Wilk test. To perform the SPC study, control charts by attributes were used, in which the number of non-conformities present in each sample was raised. The procedures followed those described by Montgomery (2012), and the SPC limits were determined with the aid of Equations 1, 2, and 3.

$$
\begin{array}{ll}
U C L=p^{\prime}+3 \sqrt{\left[\frac{p \prime\left(1-p^{\prime}\right)}{n}\right]} & \text { (Equation 1) } \\
M L=p^{\prime} & \text { (Equation 2) } \\
L C L=p^{\prime}-3 \sqrt{\left[\frac{p^{\prime}\left(1-p^{\prime}\right)}{n}\right]} & \text { (Equation 3) }
\end{array}
$$

Where: UCL $=$ upper control limit; $\mathrm{LCL}=$ lower control limit; ML = midline; $\mathrm{p}^{\prime}=$ fraction of defective (non-compliant); $\mathrm{n}=$ sample number.

After elaborating the control charts, the interpretations followed the recommendations of Trindade et al. (2007) and Montgomery (2012), being: I) Data within the control limits, indicating a process under statistical control; II) Data within the control limits, but with tendencies in the process to extrapolate the limits; and, III) Data below or above the control limit, indicating variability and inconsistency in the process.

For the study of the origins of process variability, a Pareto chart was created, aiming to raise non-conformities, ordering them in a decreasing way with the frequency in which they occurred, classifying these non-conformities as "trivial" or "vital" problems, identifying the problems with the greatest potential to compromise the production process.

After identifying the causes of variability, corrective actions were suggested to solve the problems found in the production chain. These suggestions were recommended through a Brainstorming session made with a multidisciplinary team composed of engineers, technicians, academics, people interested in the studied topic, 
literature, and supported by the CEDAE nursery technical team.

\section{Results and discussion}

It is noticed that the forest seedling production process is out of statistical control, since a single point, relative to sample 26 , is located below the established lower control limit (LCL), as shown in Figure 1.

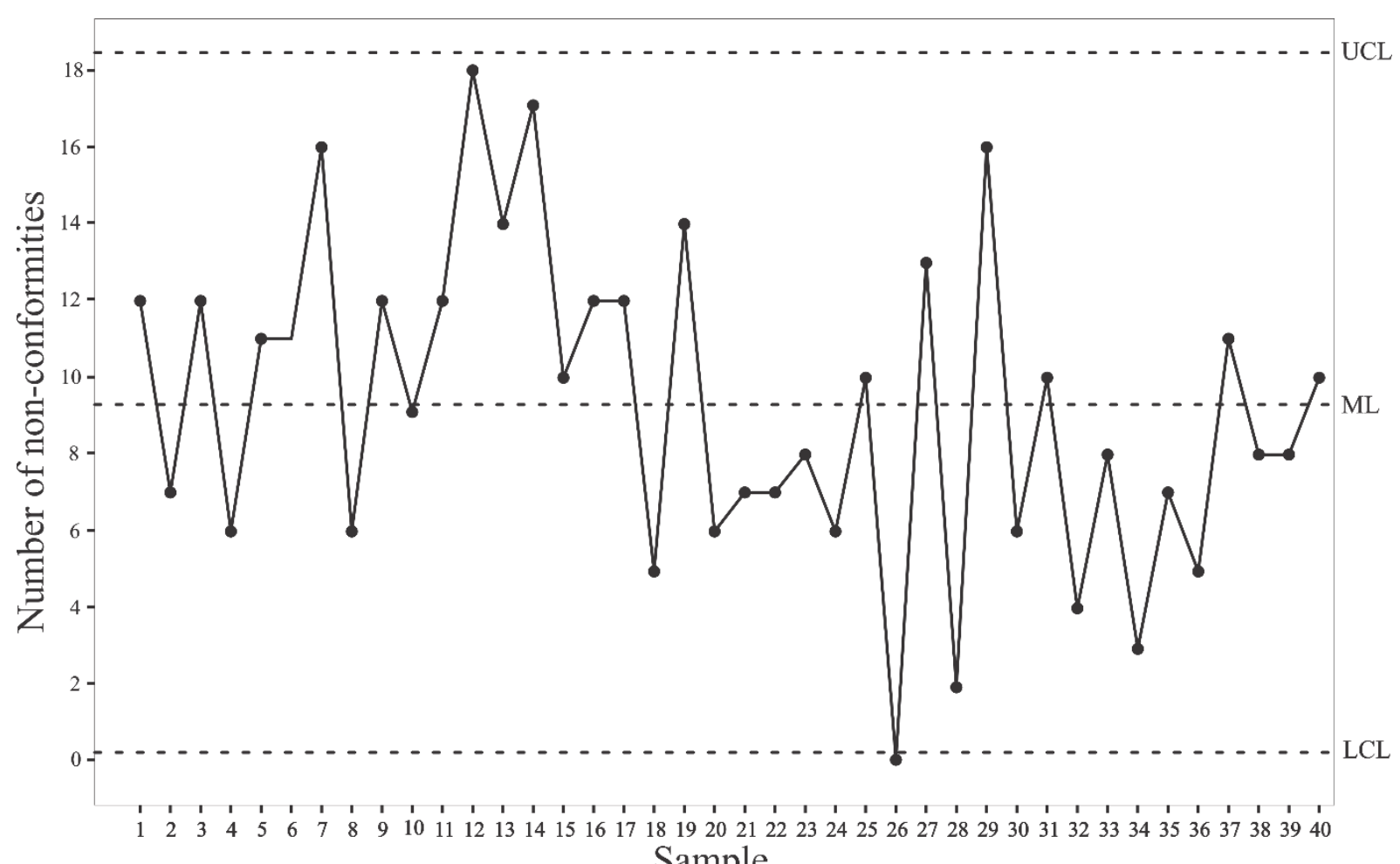

Figure 1. Statistical process control of non-conformities analyzed from forest seedlings. Where: UCL = upper control limit; $\mathrm{LCL}=$ lower control limit; $\mathrm{ML}=$ midline.

Considering that the seedlings to be sent to the field need a high-quality standard (to resist different climatic adversities), the results shown in Figure 1 suggest a review of the seedling production process, aiming at the adequacy of the container filling methodology as well as re-evaluating the type of substrate used. Campo et al. (2010), studying the production process of Quercus ilex L. seedlings, stated that the production phase in the nursery can influence the final quality of the seedling and, therefore, the success of the planting.

It is also important to highlight that the points of non-conformity were slightly dispersed from the midline (ML), with a tendency to approach the upper and lower limits (Figure 1). This result demonstrates that non-conformities show variability due to incorrect procedures that may have been carried out throughout the seedling production process. Trindade et al. (2007) mention that the dispersion of points in relation to the midline as well as the presence of points adjacent to the stipulated limits are characteristics of a process with a tendency to get out of statistical control and that such performance could be related to the systematic errors that occur throughout the production process.
Within statistical control, when many points are not outside the limits but concentrated away from the ML, it can indicate that the process tends to have problems (high variability). For Trindade et al. (2007), the repetition of peaks throughout the process is an indication of a process close to getting out of control. This form of behavior was identified in this study (Figure 1) and was highly demonstrated between points 25 to 30 . These inconsistencies can originate in the workforce used, pointing out the need for improving the operators, since those used in the nursery of CEDAE involve people serving a judicial sentence in a total imprisonment regime ("convicted" workforce). Considering that the nursery workers are serving the last years of their sentence, that they have no previous experience in the production of seedlings and that the average length of stay in this nursery is only six months, capacity building and training can be an important ally to improve the production process.

Looking at Figure 2, it can be seen that the evidence of attack by phytopathogens and/or herbivory that occurred in the seedlings was the nonconformity that had the highest frequency, 32.89\%. Secondly, seedlings that had roots fixed to the ground represented $26.14 \%$ of non-conformities, and 
the presence of entangled roots, $24.80 \%$. Seedlings with disintegrated substrate represented $15.63 \%$ of non-conformities and seedlings that had nutritional deficiency only $0.54 \%$.

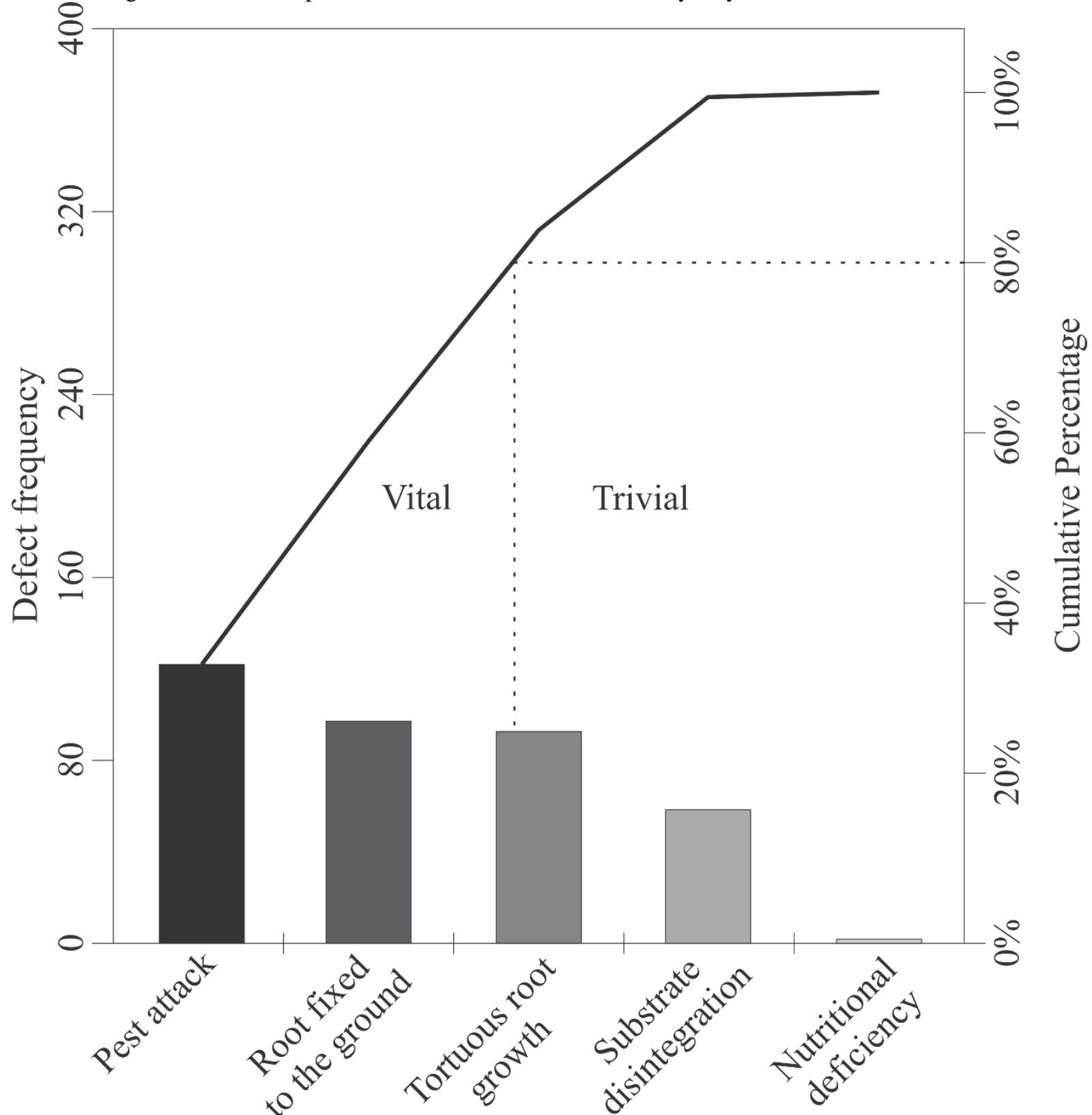

Figure 2. Pareto chart of the defect frequencies and cumulative percentage of non-conformities detected in seedlings in the nursery.

Montgomery (2012) declares that, even if a process is under control, but with many nonconformities deviating from the ML, it is advisable to make some interventions in the process to reduce this dispersion. After evaluating the processes using the SPC tool, corrective actions can be indicated to solve the detected problems.

For the attack of phytopathogens and herbivores, all seedlings that showed at least one indication of herbivory, presence of fungi and/or small insects were considered non-conformity, even if they were not in a situation considered critical, which explains the high rate of observation of this non-conformity. This non-conformity is important, since the identification and control at milder levels can avoid significant losses in the forest seedling production process.

Seedlings that have roots stuck to the soil are usually linked to the period of stay in the nursery. As the CEDAE nursery does not sell seedlings, its production is highly dependent on the planting pace of the field teams and on the demand by partner institutions, which is irregular during the year, making production and expedition planning difficult. Such observations are also made in commercial nurseries that require demands for the preparation and dispatch of seedlings. Some corrective actions, such as the movement and 
classification of seedlings, combined with the pruning of the roots, are activities that require high labor, but are essential to avoid this type of nonconformity.

This non-conformity can reduce the final quality of the seedlings, due to the limited space for the root system to develop, being able to change the architecture of the roots in addition to leaving the seedling more vulnerable to diseases (Alfenas et al. 2009). Mafia et al. (2005) demonstrated in their research that the seedlings that remained for long periods in the nursery tended to show deformations in their root systems and reductions in their growth rates.

Root coiling can be generated for two main reasons, the first when the seedling remains in the nursery for a long time and its roots wrap around the base of the production container, or even when an error occurs when the seedlings are transplanted to the containers (Nabayi et al. 2017). Transplanting is one of the most important activities, as it represents $90 \%$ of the process, so standardization is necessary. Silva et al. (2012) states that the good morphological development of the roots is highly correlated with the quality of the root system.

The non-formation of the clod, when the substrate disintegrates when removed from the container, can expose the root system, hampering the development of seedlings in the field, which can result in mortality. This non-conformity can occur due to two factors, related to the inadequate formulation of the substrate, or even due to the inadequate filling of the containers (Vidal and Rodrigues 2019). Oliveira et al. (2016) states that the operator's practice is essential when filling the container with the substrate so that the clod does not disintegrate when the seedling is extracted from the packaging, and so that the substrate is not too compacted, which can lead to poor development of the root system. Considering that all the seedlings analyzed were produced using the same substrate and that there was a low incidence of this nonconformity, the main cause can be linked to failures or inadequate procedures in filling the containers. This non-conformity can also be overcome by qualification and training of workers.

Even though the nursery does not use basal or top-dressing mineral fertilization in the forest seedling production process, nutrient deficiency was the non-conformity with lowest occurrence. This fact may be related to the use of biosolids as part of the substrate used in production. Biosolid is a material rich in organic matter and nutrients and its use as a substrate has been proven to reduce the use of chemical fertilizers in nurseries (Abreu et al. 2017). Table 2 summarizes the corrections suggested by the technical team involved to remedy the inconsistencies raised.

Table 2. Corrective actions for detected non-conformities.

\section{Non-conformities}

\section{Corrective actions}

Disintegrating substrates

Coiled root growth

Roots fixed to the ground

Nutritional deficiency

Attack of pathogens and herbivores
Training employees to improve substrate placement in containers

Training employees to minimize errors in transplanting the seedlings

Planning the production of seedlings to prevent them from staying too long in the nursery, pruning the roots whenever necessary

Adoption of top-dressing fertilization only in the species or lots that are necessary

Implementation of insect traps and natural insecticides to minimize possible impacts
Silva et al. (2015) stated that the lack of specialized labor was pointed out by nurserymen as one of the biggest obstacles for the activity of production of native seedlings in the state of Rio de Janeiro, showing that this is not an isolated problem of the nursery in which this research was conducted. Given this scenario, the technical qualification of the inmates is necessary not only to improve the production process in the CEDAE nursery but also to indicate a new way for them to carry out work in the forestry area after serving their sentence.

The coiled development of roots can be corrected by minimizing the influence of the labor during the harvesting activity. To this end, it is necessary to train the workers to standardize activities. Trindade et al. (2007) point out that, to facilitate the reproduction and control of a repetitive process, some quality tools can be used, such as: making flowcharts and implementing Operational Standards.

\section{Conclusions}

Although only one sample was detected out of statistical process control, the entire seedling production process is hampered due to high level of variability of non-conformities found in forest 
seedlings, which negatively affects the quality of seedlings produced for planting in the field. To continuously improve the process, it is recommended to implement corrective actions, such as pest monitoring and control, and planning the production of seedlings.

\section{Acknowledgements}

The authors are very thankful for the funding provided by CAPES. This study was funded by the Coordenação de Aperfeiçoamento de Pessoal de Nível Superior - Brasil (CAPES) - Finance Code 001.

\section{References}

Abreu AHM, Marzola LB, Melo LA, Leles PSS, Abel ELS, Alonso JM (2017) Urban solid waste in the production of Lafoensia pacari seedlings. Revista Brasileira de Engenharia Agrícola e Ambiental, 21(2): 83-87. doi: 10.1590/18071929/agriambi.v21n2p83-87

Alarcon GG, Fantini AC, Salvador CH, Farley J (2017) Additionality is in detail: Farmers' choices regarding payment for ecosystem services programs in the Atlantic forest, Brazil. Journal of Rural Studies, 54: 177-186. doi: 10.1016/j.jrurstud.2017.06.008

Alfenas AC, Zauza AAV, Mafia RG, Assis TF (2009) Clonagem e doenças do eucalipto. $2^{\text {nd }}$ Edition. Viçosa: Editora UFV. 500p.

Alavez-Pinto HN, Latawiec AE, Strassburg BBN, Barros FSM, Sansevero JBB, Iribarrem A, Crouzeilles R, Lemgruber L, Rangel MC, Silva ACP (2017) Reconciling rural development and ecological restoration: Strategies and policy recommendations for the Brazilian Atlantic Forest. Land use Policy, 60: 419-426. doi: 10.1016/j.landusepol.2016.08.004

Bottani E, Montanari R, Volpi A, Tebaldi L, Di Maria G (2021) Statistical Process Control of assembly lines in a manufacturing plant: Process Capability assessment. Procedia Computer Science, 180: 1024-1033. doi: 10.1016/j.procs.2021.01.353

Campo AD, Navarro RM, Ceacero CJ (2010) Seedling quality and field performance of commercial stocklots of containerized holm oak (Quercus ilex) in Mediterraean Spain: an approach for stablishing a quality standard. New Forests, 39(1): 19-37. doi: 10.1007/s11056-009-9152-9

Du Y, Zhao Q, Chen L, Yao X, Zhang W, Zhang B, Zie F (2020) Effect of drought stress on sugar metabolism in leaves and roots of soybean seedlings. Plant Physiology and Biochemistry, 146: 1-12. doi: 10.1016/j.plaphy.2019.11.003
Gregorio N, Herbohn J, Harrison S, Pasa A, Ferraren A (2017) Regulating the Quality of Seedlings for Forest Restoration: Lessons from the National Greening Program in the Philippines. Small-scale Forestry, 16: 83-102. doi: 10.1007/s11842-0169344-z

Grossnickle SC, Macdonald JE (2018a) Seedling Quality: History, Application, and Plant Attributes. Forests, 9(283): 1-23. doi: 10.3390/f9050283

Grossnickle SC, Macdonald JE (2018b) Why seedlings grow: influence of plant attributes. New Forests, 49: 1-34. doi: 10.1007/s11056-017-9606-4

Haase DL, Davis AS (2017) Developing and supporting quality nursery facilities and staff are necessary to meet global forest and landscape restoration needs. Reforesta, 4: 69-93. doi: 10.21750/REFOR.4.06.45

Kim J, Lim C (2021) Customer complaints monitoring with customer review data analytics: An integrated method of sentiment and statistical process control analyses. Advanced Engineering Informatics, 49: $101304 . \quad$ doi: 10.1016/j.aei.2021.101304

Lima AAN, Lima JR, Silva JL, Alencar JRB, Soares Sobrinho JL, Lima LG, Rolim Neto PJ (2006) Aplicação do controle estatístico de processo na indústria farmacêutica. Revista de Ciências Farmacêuticas Básica e Aplicada, 27(3): 177-187.

Mafia RG, Alfenas AC, Siqueira L, Ferreira AEM, Leite HG, Cavallazzi JRP (2005) Critério técnico para determinação da idade ótima de mudas de eucalipto para plantio. Revista Árvore, 29(6): 947953. doi: 10.1590/S0100-67622005000600014

Montgomery DC (2012) Introduction to Statistical Quality Control. $7^{\text {th }}$ Edition. Arizona: Jhon Wiley \& Sons. 754p.

Moreno GR, Fernández ME, Contreras ED (in press) Balanced mixture of biochar and synthetic fertilizer increases seedling quality of Acacia mangium. Journal of the Saudi Society of Agricultural Sciences. doi: 10.1016/j.jssas.2021.04.004

Nabayi A, Teh CBS, Husni MHA, Sulaiman Z (2017) Plant Growth, Nutrient Content and Water Use of Rubber (Hevea brasiliensis) Seedlings Grown using Root Trainers and Different Irrigation Systems. Pertanika Journal of Tropical Agricultural Science, 41(1): 251-270.

Oliveira MC, Ogata RS, Andrade GA, Santos DS, Souza RM, Guimarães TG, Silva Júnior MC, Pereira DJS, Ribeiro JF (2016) Manual de viveiros $e$ 
produção de mudas. $1^{\text {st }}$ Edition. Brasília: Embrapa Cerrados. 128p.

Reis LK, Damasceno Junior GA, Battaglia LL, Garcia LC (2021) Can transplanting seedlings with protection against herbivory be a cost-effective restoration strategy for seasonally flooded environments? Forest Ecology and Management, 483: 118742. doi: 10.1016/j.foreco.2020.118742

Silva MAS, Marques HR, Santos TVMN, Teixeira AMC, Luciano MSF, Sambuichi RHS (2015) Diagnóstico de produção de mudas florestais nativas no Brasil. $1^{\text {st }}$ Edition. Brasília: IPEA. 58p.

Silva RBG, Simões D, Silva MR (2012) Qualidade de mudas clonais de Eucalyptus urophylla x $E$. grandis em função do substrato. Revista Brasileira de Engenharia Agrícola e Ambiental, 16(3): 297302. doi: 10.1590/S1415-43662012000300010

Trindade C, Rezende JLP, Jacovine LAG, Sartório ML (2007) Ferramentas da qualidade, aplicação na atividade florestal. $2^{\text {nd }}$ Edition. Viçosa: Editora UFV. 159p.

Vidal CY, Rodrigues RR (2019) Restauração da Diversidade: Os Viveiros do Estado de São Paulo. Piracicaba: ESALQ. 84p. 